\title{
CHROMOSOME NUMBERS IN COMPOSITAE. IV. AMBROSIEAE ${ }^{1}$
}

\author{
Willard W. Payne, Peter H. Raven and Donald W. Kyhos \\ Department of Botany, The University of Michigan, Ann Arbor, Michigan \\ and \\ Division of Systematic Biology, Stanford University, Stanford, California
}

\begin{abstract}
A B S T R A C T
New chromosome observations are reported for 30 species and varieties from 4 genera of Ambrosieae: Ambrosia (including Franseria), Dicoria, Hymenoclea and Iva. Neither polyploidy nor aneuploidy is known in the genera Dicorea, Hymenoclea or Xanthium. Aneuplcid reduction appears to have played a role in the genome evolution of several species of $I v a$ and Ambrosia. Polyploid species occur in both $I v a$ and $A m b r o s i a$ and polyploid series exist for at least 5 species or species aggregates of the latter. All available evidence indicates that the primitive chromosome number for the tribe is $x=18$, differentiation and speciation having occurred at this level, which is here termed diploid. The group, however, must ultimately have been of polyploid origin from forms with $x=9$.
\end{abstract}

THIS is the fourth in a recent series of papers dealing with chromosome numbers in various tribes of the Compositae. Materials and methods are generally those discussed in carlier contributions to this series, the most recent of which is Ornduff et al. (1963). Procedural details have varied somewhat since work was carried out independently by the various workers. We are indebted to Dr. Arthur Cronquist for his determination of Iva nevadensis, to Dr. A. G. Norman, Director of the University of Michigan Botanical Gardens, for arranging maintenance of many of the plants for which observations are reported, and to Dr. W. H. Wagner, Jr. and Dr. B. L. Turner for their reviews of the manuscript.

The ragweeds and their relatives are commonly classified as a subtribe, Ambrosiinae, of the tribe Heliantheae, but a number of attributes, present in all of the genera incorporated ( $I v a$-including Leuciva, Oxytenia, Chorisiva and Cyclachaena, Dicoria, Euphrosyne, Hymenoclea, Xanthium, and Ambrosia [including Franseria]), may warrant elevation of the group to the position of a tribe within the present tribal structure of the Compositae. 'I hese include: (1) the development of anemophily and its associated modification and reduction of capitula and florets; (2) the nodding insertion of staminate or androgynous heads on the inflorescence axis; (3) the indeterminant development pattern of the racemose or spicate inflorescences; (4) the weakly connate nature of the stamens of staminate florets; (5) the development of bladder-like air chambers in the intercolpoidal regions of the exine of the pollen wall. As a group, these plants appear to be related to both the Heliantheae and the Anthemideae but are removed from both through specialization

${ }^{1}$ Received for publication August 23, 1963.

Publication no. 36 on Atmospheric Pollution by Aeroallergens, Botanical Phase, under Research Grant No. AP-00008-02 from the Division of Air Pollution, Bureau of State Services, Public Health Service.
(Payne, 1963). For the present, therefore, we have deemed it the best course to recognize the group as a distinct tribe, the Ambrosieae, a treatment which follows the precedents of Cassini (1834) and Delpino (1871), and which agrees in general meaning with the remarks or treatments of Bentham (1873), Small (1913), Rydberg (1922) and others.

The occurrence of hybridization, evident crossrelationships in several parts of both genera, and poor morphological distinctions (Gebben, Payne, and Wagner, 1962; Payne, 1962, 1963) all lead the authors to accept the proposal of Shinners (1949) that Franseria and Ambrosia are congeneric. Detailed evidence for this and a conspectus of the combined genus, Ambrosia, will be presented in a forthcoming paper by Payne. For the purposes of this paper we shall treat all species for which binomials are available under Ambrosia and leave the remainder, for the time being, under Franseria.

Table 1 includes, unless otherwise noted, original, meiotic chromosome counts for listed members of Ambrosieac. Meiotic irregularities are indicated by footnotes. Collection numbers preceded by $P$ are by Payne and by $R$ are by Raven. Herbaria in which voucher specimens are deposited are indicated immediately after the collection numbers. Camera lucida drawings of previously unreported chromosome complements, representative for 17 clones or populations of 4 ragweed species, are shown in Fig. 1.

With the material in Table 1 , some of which repeats or verifies counts reported in the literature, chromosome counts are available for members of all 6 of the genera currently recognized in the Ambrosieae, except for the monotypic, Mexican genus, Euphrosyne. In the genus Iva (including Oxytenia, etc.) numbers have been reported for 14 of the 19 species recognized by Jackson (1960). Counts are available for all 3 species of Hymenoclea, for 1 of the 4 closely 


\begin{tabular}{|c|c|c|}
\hline Species & $\begin{array}{c}\text { Gametic } \\
\text { chromosome } \\
\text { number }\end{array}$ & Locality, collection and voucher location \\
\hline \multicolumn{3}{|l|}{ Ambrosia (Franseria) } \\
\hline \multirow[t]{3}{*}{ A. acanthicarpa } & $18^{\mathbf{a}}$ & Madera Co., Calif., $P-A H I-2323$ (MICH; garden progeny) \\
\hline & 18 & San Bernardino Co., Calif., R-16678 (RSA) \\
\hline & 18 & Washoe Co., Nev., R-16785 (MICH) \\
\hline \multirow[t]{2}{*}{$F$. ambrosioides } & $18^{\mathrm{a}}$ & Maricopa Co., Ariz., P-2699 (MICH) \\
\hline & 18 & Sonora, Mexico, $R$-11687 (UC) \\
\hline A. artemisiifolia & $18^{\mathrm{a}}$ & Laramie Co., Wyo., P-AOT-3034 (MICH; garden progeny) \\
\hline A. a. "var. maritima" & $18^{\mathrm{a}}$ & Nancy, France, $P$-AIR-2324 (MICH; garden progeny) \\
\hline A. bryantii & $18^{\mathrm{a}}$ & Baja California, Mexico, Porter 456 (MICH) \\
\hline F. camphorata & $36(\mathrm{G})^{\mathrm{b}}$ & San Luis Potosí, Mexico, $P-4175$ (MICH) \\
\hline A. canescens & $18(\mathrm{C})^{\mathrm{b}}$ & Aguascalientes, Mexico, $P$-4051 (MICH) \\
\hline \multirow[t]{2}{*}{ F. chamissonis } & $18^{\mathrm{a}}$ & Marin Co., California, P-2795 (MICH) \\
\hline & 18 & San Francisco, Calif., R-16558 (MICH) \\
\hline \multirow[t]{2}{*}{$F . c$. ssp. bipinnatisecta } & $18^{\mathbf{a}}$ & Marin Co., Calif., $P$-2783 (MICH) \\
\hline & 18 & San Francisco, Calif., R-16559 (MICH) \\
\hline \multirow[t]{2}{*}{ F. chenopodiifolia } & $36^{\mathbf{c}}$ & Baja California, Mexico, R-12197 (UC) \\
\hline & $36^{\mathrm{d}}$ & Baja California, Mexico, $R-17038$ (UC) \\
\hline A. chieranthifolia & $36(\mathrm{P})^{\mathrm{b}}$ & Nueces Co., Texas, $P-A V G-4356$ (MICH; garden progeny) \\
\hline \multirow[t]{2}{*}{ A. confertiflora } & 36 & Los Angeles Co., Calif., $R-16785$ (JEPS) \\
\hline & 36 & Los Angeles Co., Calif., R-16844 (JEPS) \\
\hline \multirow[t]{2}{*}{ A.c. var. tenuifolia } & $54(\mathrm{~F})^{\mathrm{b}}$ & \\
\hline & $36^{\mathbf{a}}$ & Los Angeles Co., Calif., P-AIG-2984 (MICH; garden progeny) \\
\hline A. cumanensis & $18(\mathrm{D})^{\mathrm{b}}$ & Vera Cruz, Mexico, P-3841 (MICH) \\
\hline A. deltoidea & $18^{e}$ & Sonora, Mexico, R-14807 (MICH) \\
\hline A. eriocentra & 18 & San Bernardino Co., Calif., Balls 22495 (RSA) \\
\hline A. grayi & $18^{\mathrm{a}}$ & McPherson Co., Kans., P-2621 (MICH) \\
\hline A. hispida & $72^{\mathrm{a}}$ & Monroe Co., Fla., $P-A H K-3142$ (MICH; garden progeny) \\
\hline \multirow[t]{2}{*}{$F$. ilicifolia } & $\begin{array}{l}18^{a} \\
18\end{array}$ & Yuma Co., Ariz., $P$-AJO-3089 (MICH; garden progeny) \\
\hline & 18 & Sonora, Mexico, R-14807 (MICH) \\
\hline \multirow{6}{*}{ A. psilostachya } & $\begin{array}{l}36^{\mathbf{a}} \\
36^{\mathrm{a}}\end{array}$ & Jamaica, West Indies, $P-A I U-9143$ (MICH; garden progeny) \\
\hline & $\begin{array}{l}36^{\mathbf{a}} \\
36^{\mathrm{a}}\end{array}$ & Bay Co., Mich., P-1619 (MICH) \\
\hline & $\begin{array}{l}36^{\mathrm{a}} \\
36(\mathrm{E}) \mathrm{b}\end{array}$ & Tulsa Co., Okla., $P-A L C-3347$ (MICH; garden progeny) \\
\hline & $\begin{array}{l}36(\mathrm{E})^{\mathrm{b}} \\
36(\mathrm{H})^{\mathrm{b}}\end{array}$ & Querétaro, Mexico, P-8867 (MICH) \\
\hline & $\begin{array}{l}36(\mathrm{H})^{b} \\
36(\mathrm{I})^{\mathrm{b}}\end{array}$ & MePherson Co., Kans., $P$-AJC-4225 (MICH; garden progeny) \\
\hline & $\begin{array}{l}36(1)^{b} \\
36(J)^{b}\end{array}$ & \\
\hline \multirow[t]{5}{*}{ A. psilostachya } & $\begin{array}{l}36(\mathrm{~J})^{\mathrm{b}} \\
54(\mathrm{~K})^{\mathrm{b}}\end{array}$ & $\begin{array}{l}\text { Durango, Mexico, } P-4141 \text { (MICH) } \\
\text { Lamar Co. Texas, } P-3649 \text { (MICH) }\end{array}$ \\
\hline & $\begin{array}{l}54(\mathrm{~K})^{\mathrm{b}} \\
54(\mathrm{~L})^{\mathrm{b}}\end{array}$ & $\begin{array}{l}\text { Lamar Co., Texas, } P-3649 \text { (MICH) } \\
\text { Coahuila, Mexico, } P-3768 \text { (MICH) }\end{array}$ \\
\hline & $54(\mathrm{M})^{\mathrm{b}}$ & $\begin{array}{l}\text { Coahuila, Mexico, P-9768 (MICH) } \\
\text { Coahuila, Mexico, P-9769 (MICH) }\end{array}$ \\
\hline & $54(\mathrm{~N})^{\mathrm{b}}$ & $\begin{array}{l}\text { Coahuila, Mexico, P-9769 (MICH) } \\
\text { Yolo Co., Calif., P-ARM-4226 (MICH; garden progeny) }\end{array}$ \\
\hline & $54(0)^{\mathrm{b}}$ & $\begin{array}{l}\text { Yolo Co., Calif, } P-A R M-4226 \text { (MICH; garden progeny) } \\
\text { Summitt Co., Utah, } P-A K S-4227 \text {; (MICH; garden progeny) }\end{array}$ \\
\hline A. psilostachya & $72^{\mathrm{a}}$ & $\begin{array}{l}\text { Summitt Co., Utah, } P-A K S-4287 \text {; (MICH; garden progeny) } \\
\text { Yolo Co., Calif., } P-A L E-2975 \text { (MICH; garden progeny) }\end{array}$ \\
\hline A. pumila & $36^{\mathrm{a}}$ & $\begin{array}{l}\text { Yolo Co., Calif., } P-A L E-2975 \text { (MICH; garden progeny) } \\
\text { San Diego Co., Calif., } P-2718 \text { (MICH) }\end{array}$ \\
\hline \multirow{4}{*}{ A. trifida } & $12^{\mathrm{a}}$ & $\begin{array}{l}\text { San Diego Co., Calif., P-2718 (IMCH) } \\
\text { Leiden, Netherlands, } P-A H N-2919 \text { (MICH; garden progeny) }\end{array}$ \\
\hline & $12^{\mathfrak{a}}$ & Leiden, Netherlands, $P-A H U-2525$ (MICH; garden progeny) \\
\hline & $12(\mathrm{~A})^{\mathrm{b}}$ & $\begin{array}{l}\text { Lenawee Co., Mich., } P-A H \text { (MICH) } \\
\text { Dallas Co., Texas, } P-3654 \text { (MId garden progeny) }\end{array}$ \\
\hline & $12(\mathrm{~B})^{\mathrm{b}}$ & Dallas Co., Texas; $P$-3658 (MICH) \\
\hline \multicolumn{3}{|r|}{ 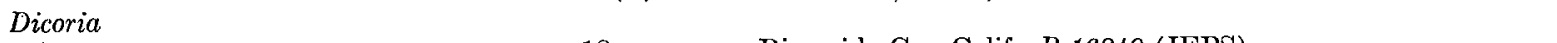 } \\
\hline D. canescens & 18 & Riverside Co., Calif., $R-16840$ (JEPS) \\
\hline \multicolumn{3}{|l|}{ Hymenoclea } \\
\hline H. monogyra & 18 & San Bernardino Co., Calif., $R-16677$ (JEPS) \\
\hline$H$. pentalepis & 18 & $\begin{array}{l}\text { San Bernardino Co., Calif., Munz } 21518 \text { (RSA, garden } \\
\text { progeny) }\end{array}$ \\
\hline H. salsola & 18 & Riverside Co., Calif., R-11414 (MICH) \\
\hline \multicolumn{3}{|r|}{ - } \\
\hline I. annua & $17^{\mathrm{s}}$ & Athens Co., Ohio, P-1944 (MICH) \\
\hline \multirow[t]{4}{*}{ I. axillaris ssp. robustior } & 18 & Lassen Co., Calif., $R-13265$ (JEPS) \\
\hline & 18 & Elko Co., Nev., $R$-13517 (JEPS) \\
\hline & $2 n=54^{i}$ & Douglas Co., Nev., R-14292 (MICH) \\
\hline & $2 n=54^{f}$ & Fresno Co., Calif., $R-15096$ (MICH) \\
\hline
\end{tabular}

a These counts have appeared previously in Gebben, Payne, and Wagner (1962) and in Payne (1962). They are reiterated here because of the general non-availability of those reports.

$b$ Letters refer to drawings in Fig. 1.

- Plus an extra pair of chromosomes.

d Plus a fragment.

- Plus 2 unpaired univalents.

With a high proportion of trivalents. $R-1$ 4292 had up to 13 trivalents, 5 pairs, and 5 univalents (cf. Bassett, Mulligan, and Frankton, 1962, p. 1246). 

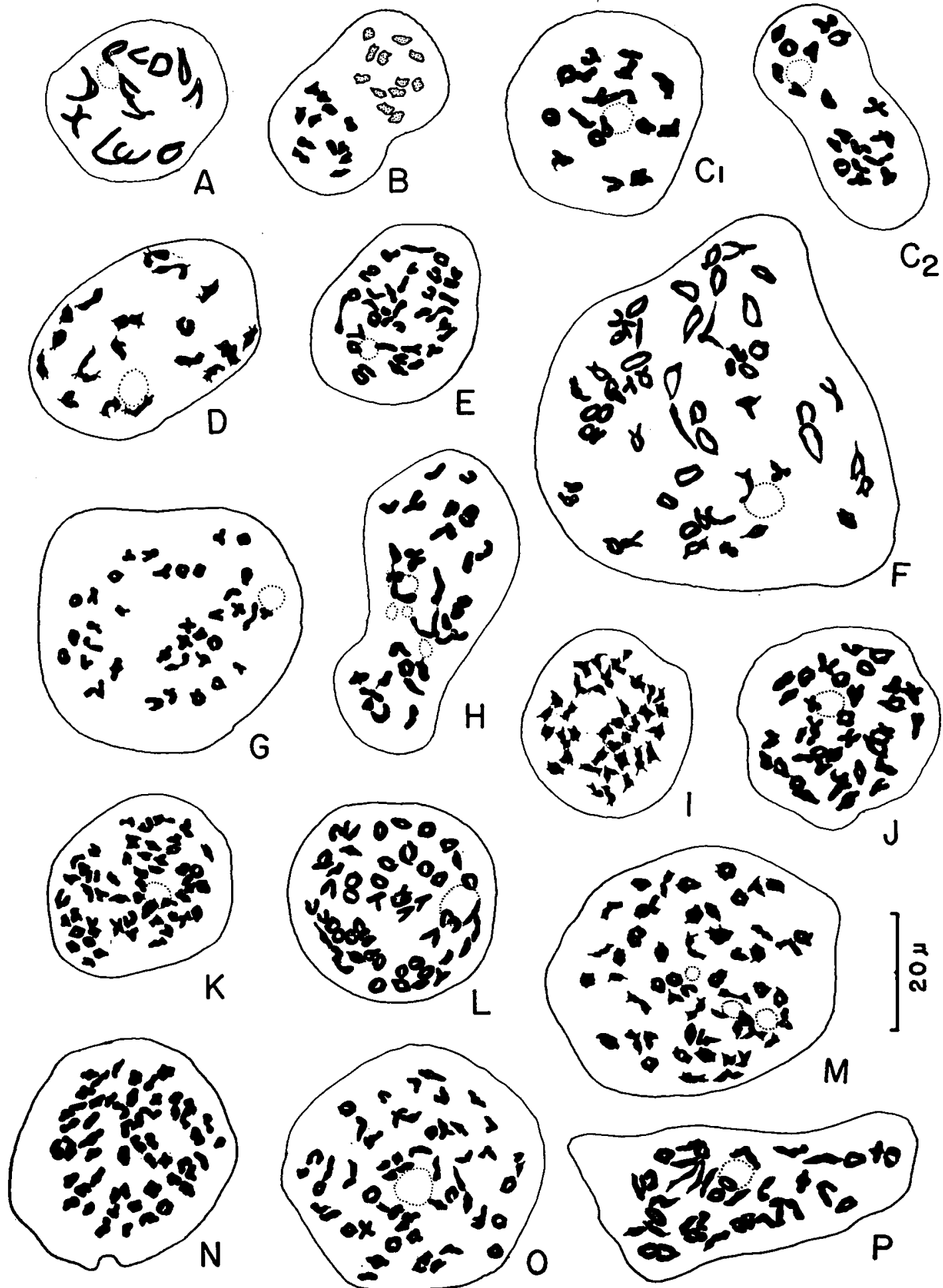

Fig. 1. Camera lucida drawings of meiotic chromosome configurations of various ragweed species. For details see text and Table 1. A, B. Ambrosia trifida L. $(n=12)$.-C. A. canescens (Benth.) Gray $(n=18)$. -D. A. cumanensis H. B. K. $(n=18)$. - E. A. psilostachya DC. $(n=36)$. -F. A. conferiffora DC. $(n=54)$. - G. Franseria camphorata Greene $(n=36)$. - H-J. A. psilostachya DC. $(n=36) .-\mathrm{K}-\mathrm{O}$. A. psilostachya DC. $(n=54)$. - P. A. cheiranthifolia Gray $(n=36)$. 
related species of Dicoria, for both species of Xanthium, sensu Löve and Dansereau (1959), and for 24 of the approximately 30 species or species aggregates of Ambrosia (including Franseria). Thus, information is available for nearly $75 \%$ of the tribe. In the following account, species with $n=18$ will be termed "diploid."

Neither polyploidy nor aneuploidy is known in the small, relatively homogeneous genera Dicoria, Hymenoclea and Xanthium, all species of which have $n=18$, so far as is known.

Three basic numbers have been recognized in Iva (Jackson, 1960)-x $=16,17$ and 18 , which have been hypothesized to represent polyploid types derived from lower numbers, such as 8,9 and 10 , found in the Heliantheae. However, the question of the original chromosome number for the genus has not been answered. In view of the rather thorough sampling of Ambrosieae, with the fact that no species with $n=8$ or $n=9$ have been discovered, and assuming Iva to be monophyletic, we believe the most likely hypothesis is that the basic number of Iva is $n=18$, and that genomes of $n=16$ and $n=17$ have been derived by aneuploid reduction. This would be in accordance with Jackson's (1960, f. 11) ideas of the evolution of the genus. If Iva axillaris $(n=18)$ has been derived from $I$. hayesiana $(n=17)$ as Jackson suggests, both ascending and descending changes in chromosome number have occurred in the phylogeny of Iva. Polyploidy has been reported in only 1 species of Iva, $I$. dealbata, in which $n=36$ (Jackson, 1960). Iva xanthifolia has been reported as having both $n=$ 18 (Jackson, 1960) and $n=17$ (Mulligan, 1959), and, therefore, deserves further investigation. Among the ragweeds (Ambrosia, including Franseria) the predominance of $x=18$ is striking. Of the 24 species studied in this group, some of which appear to be polyploid complexes or aggregates, only 2 deviate from the basic pattern of $x=18-A$. bidentata $(n=17)$ and A. trifida $(n=12)$. Both are among the most highly specialized ragweeds, and it seems very unlikely that counts for either of these species represent basically lower numbers for this genus. Both have probably been derived by aneuploid reduction, as suggested by Jones $(1933,1943)$ on the basis of chromosome pairing in interspecific hybrids. Both are weedy annuals, and their reduced chromosome number accords with the suggestions made by Stebbins $(1950,1958)$ as to the importance of a reduced rate of recombination in such plants.

Polyploid series have been reported in at least 5 ragweed species or aggregates: Franseria chenopodiifolia $-F$. deltoidea, $F$. dumosa agg., Ambrosia confertiflora agg., A. psilostachya and $A$. peruviana. Available counts for the first-mentioned group are few but suggest that Franseria deltoidea has $n=18$, whereas the closely similar $F$. chenopodiifolia has $n=36$.

Franseria dumosa is a small shrub of the northern Sonoran Desert which is strikingly different from other ragweed species in the organization of its inflorescence. Chromosome numbers of $n=18,36$ and 54 have been counted in this species, and 1 specimen has been found to have $n=62$ or 63 , which suggests the possible existence of plants with $n=72$. Plants of $F$. dumosa, at the diploid versus the polyploid levels, appear strikingly different in the field, in morphology as well as in time of blooming and ecological preferences. It appears likely that further study will result in taxonomic subdivision of this complex.

Ambrosia confertiflora, the third group in which different levels of polyploidy have been observed, is an extremely variable complex with little information as yet available as to the possible relationship of the different ploidal levels to recognized variants.

The numbers $n=36,54$ and 72 have been observed in $A$. psilostachya, an herbaceous, rootpropagating perennial found throughout the central United States and Mexico. Like several other widespread weedy species in this genus, it is very heteromorphic and has a confusing taxonomic history. In general, $n=36$ predominates in populations from the northern and eastern United States where the plants are often distinguished as var. coronopifolia or $A$. coronopifolia. Western populations tend to have $n=54$ and are often distinguished as true $A$. psilcstachya. Although it has been suggested that the occurrence of the different ploidal levels is correlated with the 2 taxa (Wagner and Beals, 1958), recent studies (Payne, 1962) indicate that the morphological correlations are relatively weak, with most specimens being at least partially intermediate. Similarly, a specimen from Yolo County, California, with $n=72$ is in no way distinctive from other specimens of the same area having $n=54$. Thus, while the occurrence of different ploidal levels undoubtedly restricts outbreeding to members of the same ploidal groups, these cannot be effectively characterized so as to provide useful species or subspecies distinctions at the present time.

Ambrosia peruviana has been observed to have both $n=18$ (Turner, Powell, and King, 1962) and $n=36$ (present account). However, the nature of this species is very ambiguous at present, and the name, as commonly used, probably incorporates elements of 2 groups, typical $A$. peruviana and $A$. cumanensis. These may, in turn, be subspecific members of $A$. psilostachya $(n=36,54,72)$ and $A$. artemisiifolia $(n=18)$, respectively. As with $A$. confertiflora, above, it is impossible at present to adequately assess the cytology of this complex.

In Table 2 the various ragweed species for which counts are available are arranged to show correlations between habit, ploidal level and weediness. All of the annual species which occur abundantly in association with man as weeds of primary sites are diploids or aneuploids pre- 
TABLE 2. Species and species complexes of Ambrosia (Franseria) arranged according to plant habit and ploidal level and scored for more or less aggressive weediness

\begin{tabular}{|c|c|c|c|c|c|}
\hline Species (Ambrosia-Franseria) & Annual & $\begin{array}{c}\text { Perennial } \\
(\mathrm{X}=\text { herb } \\
\mathrm{XX}=\text { shrub) }\end{array}$ & $\begin{array}{l}\text { Diploid (X) } \\
\text { Aneuploid } \\
(\mathrm{XX})\end{array}$ & Polyploid & $\begin{array}{l}\text { Strongly } \\
\text { ruderal } \\
\text { plants }\end{array}$ \\
\hline $\begin{array}{l}\text { A. acanthicarpa } \\
\text { A. artemisizfolia } \\
\text { A. bidentata } \\
\text { A. trifida } \\
\text { A. cumanensis } \\
\text { A. canescens } \\
\text { A. grayi (F. tomentosa) } \\
\text {. artemisioides } \\
\text { A. polystachya } \\
\text { A. bryantii } \\
\text { F. deltoidea } \\
\text { A. chamissonis (bipinnatifida etc.) } \\
\text { F. ambrosioides } \\
\text { F. ilicifolia } \\
\text { F. eriocentra } \\
\text { F. dumosa } \\
\text { A. periviana } \\
\text { A. cheiranthifolia } \\
\text { A. psilostachya } \\
\text { A. confertiflora } \\
\text { A. pumila } \\
\text { A. hispida } \\
\text { F. camphorata } \\
\text { F. chenopodiifolia }\end{array}$ & $\begin{array}{l}X \\
X \\
X \\
X\end{array}$ & $\begin{array}{l}\mathrm{X} \\
\mathrm{X} \\
\mathrm{X} \\
\mathrm{X} \\
\mathrm{X} \\
\mathrm{XX} \\
\mathrm{XX} \\
\mathrm{XX} \\
\mathrm{XX} \\
\mathrm{XX} \\
\mathrm{XX} \\
\mathrm{XX} \\
\mathrm{X} \\
\mathrm{X} \\
\mathrm{X} \\
\mathrm{X} \\
\mathrm{X} \\
\mathrm{X} \\
\mathrm{XX} \\
\mathrm{XX}\end{array}$ & $\begin{array}{l}\mathrm{X} \\
\mathrm{X} \\
\mathrm{X} X(n=17) \\
\mathrm{XX}(n=12) \\
\mathrm{X} \\
\mathrm{X} \\
\mathrm{X} \\
\mathrm{X} \\
\mathrm{X} \\
\mathrm{X} \\
\mathrm{X} \\
\mathrm{X} \\
\mathrm{X} \\
\mathrm{X} \\
\mathrm{X} \\
\mathrm{X} \\
\mathrm{X}\end{array}$ & $\begin{array}{l}\mathrm{X} \\
\mathrm{X} \\
\mathrm{X} \\
\mathrm{X} \\
\mathrm{X} \\
\mathrm{X} \\
\mathrm{X} \\
\mathrm{X} \\
\mathrm{X}\end{array}$ & $\begin{array}{l}\mathrm{X} \\
\mathrm{X} \\
\mathrm{X} \\
\mathrm{X} \\
\mathrm{X} \\
\mathrm{X} \\
\mathrm{X} \\
(?) \\
(?)\end{array}$ \\
\hline
\end{tabular}

sumably derived from diploids. These species tend to occur predominantly in northerly portions of the genus range. Of the weedy, herbaceous perennial species, 3 are diploid, 4 are polyploid and $1, A$. peruviana, may have both diploid and tetraploid races. However, of these perennials, only $2, A$. psilostachya and A. confertiflora, are abundant ruderal weeds with relatively extensive ranges. The perennial herbaceous species occur predominantly in the southwestern United States and Mexico in prairie and arid region associations, where their perennial nature may give them competitive advantage over annuals. Of the 9 shrubby species listed in Table 2 , all but $3, F$. camphorata, $F$. chenopodiifolia and $F$. dumosa, are diploid and the $F$.dumosa aggregate includes diploid members. These shrubby ragweeds include many of the less specialized species, as judged on the basis of floral morphology (Payne, 1963) and other characteristics. Their predominantly diploid nature supports placement near the beginning of the evolutionary scheme for the genus. Both annual and perennial, herbaceous species appear to have differentiated from shrubby progenitors on the diploid level. Polyploidy has developed in the evolution of several of the perennial herb complexes and in 3 of the shrub complexes, while aneuploid reduction has taken place during the evolution of the most specialized annuals.

In summary, the immediate basic chromosome number for the Ambrosieae appears to have been $x=18$, with aneuploid reduction proceeding independently in Iva to produce genomes of $n=$ 17 and $n=16$, and in Ambrosia to produce genomes of $n=17$ and $n=12$. The tribe is, therefore, postulated to have had a polyploid origin, presumably derived from non-ambrosioid composites with $n=9$, and to have diversified from the immediate ancestral group on the polyploid level. There is no evidence at present that species with $n=9$ that had attained the morphological characteristics of Ambrosicae ever existed. The ragweeds have proliferated chiefly in the subarid and dry subtropical regions of southwestern North America, where many of the least specialized species, as judged on the basis of floral morphology and other characters, are endemic. It appears probable, therefore, that they actually originated in or near this region which still supports a rich flora of less specialized ragweed relatives.

\section{LITERATURE CITED}

Bassett, I. J., G. A. Mulligan, and C. Frankton. 1962. Poverty weed, Iva axillaris, in Canada and the United States. Canad. Jour. Bot. 40: 1243-1249.

Bentham, G. 1873. Notes on the classification, history and geographical distribution of Compositae. Jour. Linn. Soc. Bot. 13: 335-557. 
Cassini, H. 1826-1834. Opuscules Phytologiques. Tomes I, II, and III. Paris.

Delpino, F. 1871. Studi sopra un Lignaggio Anemophilo delle Composte ossia supra il Gruppa delle Artemisiacee. Cellini, Firenz.

Gebben, A. I., W. W. Payne, and W. H. Wagner, Jr. 1962. Botanical phase. In J. M. Sheldon and E. W. Hewson, [ed.], Atmospheric pollution by aeroallergens. Prog. Rept. 5. Univ. Mich., Ann Arbor.

JACKson, R. C. 1960 . A revision of the genus Iva $\mathbf{L}$. Univ. Kans. Sci. Bull. 41: 793-876.

Jones, K. L. 1933. Ambrosia bidentata Michx. $\times A$. trifida L. Amer. Midl. Nat. 14: 720-724.

_- 1943. Studies on Ambrosia: III. Pistillate A mbrosia elatior $\times A$. trifida and its bearing on matroclinic sex inheritance. Bot. Gaz. 105: 227-232.

Löve, D., AND P. Dansereau. 1959. Biosystematic studies on Xanthium: Taxonomic appraisal and ecological status. Canad. Jour. Bot. 37: 173-208.

Mulligan, G. A. 1959. Chromosome numbers of Canadian weeds. II. Canad. Jour. Bot. 37: 81-92.

Ornduff, R., P. H. Raven, D. W. Kyhos, and A. R. KRUCKEBERG. 1963. Chromosome numbers in Compositae. III. Senecioneae. Amer. Jour. Bot. 50: 131-139.
Payne, W. W. 1962. Biosystematic studies of four widespread weedy species of ragweeds (Ambrosia: Compositae). Ph.D. Thesis, Univ. Mich., Ann Arbor.

- - 1963. The morphology of the inflorescence of ragweeds (Ambrosia-Franseria: Compositae). Amer. Jour. Bot. 50: 872-880.

Rydberg, P. A. 1922. Ambrosiaceae. In North American flora. Vol. 33: 3-44. N. Y. Bot. Gard., New York.

Shrnners, L. H. 1949. Notes on Texas Compositae III. Field and Lab. 17: 170-176.

Small, J. K. 1913. Flora of the southeastern United States. 2nd ed. Publ. by author, New York.

Stebrins, G. L. 1950. Variation and evolution in plants. Columbia Univ. Press, New York.

- - 1958. Longevity, habitat and release of genetic variability in the higher plants. Cold Spring Harbor Sympos. 23: 365-378.

Turner, B. L., M. Powell, AND R. M. King. 1962. Chromosome numbers in the Compositae. VI. Additional Mexican and Guatamalan species. Rhodora 64: 251-271.

Wagner, W. H., JR., AND T. F. Beals. 1958. Perennial ragweeds (Ambrosia) in Michigan, with the description of a new, intermediate taxon. Rhodora 60: 117-204

Amer. Jour. Bot. 51(4): 424 -431. 1964.

\title{
PHOSPHATASE ACTIVITY AND CELLULAR DIFFERENTIATION IN PHLEUM ROOT MERISTEM ${ }^{1}$
}

\author{
Carol A. Czernik and Charlotte J. Avers
}

Department of Biological Sciences, Douglass College, Rutgers-The State University, New Brunswick, New Jersey

\section{A B S T R A C T}

Using 9 different organic phosphate substrates as alternatives in a standardized $5^{\prime}$-nucleotidase histochemical test system, enzyme activity patterns were recorded for timothy grass root epidermis. At least 4 different phosphatases were distinguished on the bases of substrate specificity, reaction rate, tissue distribution, and response to inhibitors. Except with adenosine-3'-monophosphate, all activities were restricted to the $300-\mu$-long root tip meristem. These enzyme activities were associated with the earliest phases of differentiation of the epidermal hair and hairless cell initials. The distribution of activities was not associated with the same cell type in each part of the meristem. Little activity was found with most substrates in the undifferentiated cells of the $0-100 \mu$ zone; alternating active hairless and inactive hair cell initials predominated in the $100-200 \mu$ segment; and active hair-inactive hairless sister cells formed the principal pattern in the $200-300 \mu$ segment of the meristem. The data showed that a particular enzyme activity was associated with a specific cell type only in relation to that cell's position along the differentiation gradient of the entire tissue. But, within a meristem segment, a specific cell type might act differently from its neighbors, depending on its mitotic capacity. This complex of physiological dependence and independence of a cell type on tissue ontogeny was cited as a characteristic of the phenomenon of cellular differentiation superimposed on tissue differentiation gradients.

VARIOUs studies have shown that the epidermal meristem of the Phleum root is not a homogeneous cell population. Morphological heterogeneity is

1 Received for publication August 26, 1963.

This study was aided in part by a National Science Foundation grant $(\mathrm{G}-12903)$ to the junior author. obvious upon simple inspection of the tissue. Mitotic rate and the probability for further mitoses vary in different ways along the meristematic gradient (Erickson, 1961), even though mitosis is the principal developmental process there. Growth inhibitors such as coumarin and 